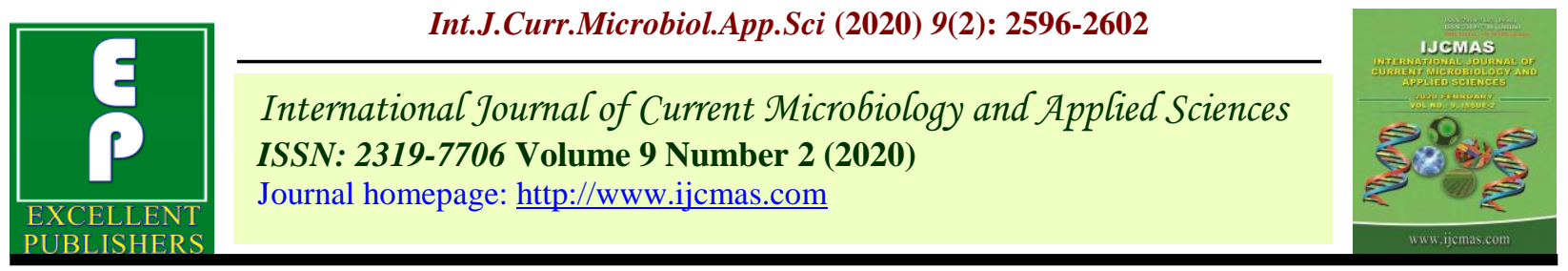

Original Research Article

https://doi.org/10.20546/ijcmas.2020.902.296

\title{
Influence of Abiotic Factors on Soil Meso-fauna in Organically Cultivated Fodder Maize Eco System
}

\author{
H. M. Mahesh* and N. G. Kumar \\ Department of Agricultural Entomology, College of Agriculture, GKVK Campus, UAS, \\ Bangalore-560065, India \\ *Corresponding author
}

A B S T R A C T

\begin{tabular}{|l|}
\hline Ke y w or d s \\
Soil meso-fauna, \\
Fodder maize, \\
Abiotic, Rainfall \\
\hline Article Info \\
\hline Accepted: \\
18 January 2020 \\
Available Online: \\
10 February 2020 \\
\hline \hline
\end{tabular}

Abiotic factors and application of organic manures influence activity of soil organisms. A field experiment was carried out at the Zonal Agriculture Research Station, UAS Bengaluru during 2014-15. There were ten treatments with varying combinations of FYM (0-20 t/ha, partially decomposed, with Glyricidia mulch) and conventional fertilizers $(0$, $25,50,75$ and $100 \%$ of 100:50:25 kg NPK /ha). Fodder maize was grown in this 13 years old plot during kharif season. Soil samples were drawn to extract meso-fauna from before application of treatments up to 300 days after germination. The results indicated that there was a significant relationship existed between the abundance of soil meso-fauna and abiotic factors. Sunshine hours and minimum temperature of the soil showed significant negative correlation with soil meso-fauna. Maximum and minimum relative humidity, total rainfall and Insitu soil moisture had significant positive correlation. The contribution of abiotic factors on the abundance of soil meso-fauna was 31.9 per cent. The influence of minimum relative humidity on the abundance of soil meso-fauna was up to 28.3 per cent. Abiotic factors like rainfall and soil moisture are known to have marked influence on soil organisms. Distribution of rainfall had significant influence on the abundance of soil mesofauna.

\section{Introduction}

Soil fauna is a group of animals which spend all or only part of their life cycle in soil. They play a significant role in the breakdown of soil organic matters to access the nutrient reservoir process. They are involved in soil formation and maintenance of soil structure. The abundance of soil meso-fauna is greatly affected by climate, intensive agriculture and different type of climatic factors (Banerjee S,
1976). The most important variables influencing soil meso-faunal communities are soil temperature, soil $\mathrm{P}^{\mathrm{H}}$ and organic matter (Klironomos and Kendrick, 1995). Occurrence of meso-fauna depends on soil type and climate interactions among these results in nutrient mineralization and immobilization. Climatic change is altering species distributions and simultaneously impacting interactions among organisms (Wookey et al., 2009). Rainfall and soil 
moisture were the major factors influencing the pattern of temporal variations in the abundance of most of the micro arthropod groups. The population density of soil Acarina of Himalayan ecosystem reached the maximum level in March, the spring season when organic carbon was at maximum level (Bhattacharya and Bhattacharya, 1987). Climatic change alters the relative abundance and function of soil communities. Detailed studies have been made on the seasonality of insect populations but there is very little information in the fluctuation of soil mesofaunal population comparing with the climatic factors.

In the present study an attempt has been made to study the influence of climatic factors on the population density of soil meso-fauna in organic farming ecosystem.

\section{Materials and Methods}

Studies were carried out at Gandhi Krishi Vignana Kendra campus of the University of Agricultural Sciences, Bengaluru during kharif season of 2014-15 under rain fed conditions. The current field experiment was laid out in a randomized complete block design with the following treatments replicated thrice.

1. Recommended fertilizers (100: $50: 25 \mathrm{Kg}$ NPK per ha) + Recommended FYM (10 tonnes per ha) + fungicide seed treatment (Carbendazim)

2. $12.5 \mathrm{t}$ of $\mathrm{FYM} / \mathrm{ha}+75$ per cent $\mathrm{NPK}$

3. 15.0 t of FYM/ha +50 per cent NPK

4. $17.5 \mathrm{t}$ of $\mathrm{FYM} / \mathrm{ha}+25$ per cent NPK

5. $20.0 \mathrm{t}$ of $\mathrm{FYM} / \mathrm{ha}$

6. $10.0 \mathrm{t}$ of $\mathrm{FYM} / \mathrm{h}$.
7. $10.0 \mathrm{t}$ of FYM/ha (partially decomposed)

8. $10.0 \mathrm{t}$ of FYM/ha + mulching (glyricidia 2 tonnes per ha.)

9. Recommended fertilizer alone

\section{0. $5.0 \mathrm{t}$ of FYM/ha}

(Note: N, P, K- Nitrogen, Phosphorous, Potassium. FYM- Farm yard manure)

The fodder maize variety 'African tall' was sown with a spacing of $30 \times 10 \mathrm{~cm}$ in $6 \times 3.6 \mathrm{~m}$ sub plot on $9^{\text {th }}$ August 2014. Crop was raised under rainfed conditions. The soil samples were collected before imposition of treatments and on 10, 20,30, 45, 60, 75, 90 and 105 days after germination in each treatment. The samples were also collected at 15 days interval during non-cropping season, totally for a period of 300 days. The samples were collected using the circular core sampler measuring $12 \mathrm{~cm}$ diameter and $10 \mathrm{~cm}$ height. The meso-fauna was extracted from the soil samples using Rothamsted modified MacFadyen high gradient funnel apparatus. The fauna collected were preserved in $70 \%$ alcohol and identified in a stereo binocular microscope. Weather parameters such as soil moisture and soil temperature were recorded at each sampling time in the experimental site. Soil temperature was recorded by inserting a soil thermometer into the soil to a depth of $10 \mathrm{~cm}$ at the time of each sampling period in each plot. Abiotic factors viz., atmospheric temperature ( $\max$ and $\min$ ), relative humidity ( $\max$ and $\min$ ), sunshine hours and rainfall of the experimental location were collected from the meteorology department, UAS, GKVK, Bengaluru-65. The best treatment favoring meso-fauna was correlated with the abiotic factors of the experimental location. The correlation coefficients were worked out by adopting multiple correlation analysis to find out the 
relationship between the abundance of soil meso-fauna and abiotic factors.

\section{Results and Discussion}

\section{Abundance of soil meso-fauna}

The abundance of soil meso-fauna differed significantly among the intervals. It varied from 3.00 at 15 days before application of treatments (BAT) to 27.70 meso-fauna / $400 \mathrm{~g}$ of soil at 90 days after germination (DAG). In this study, there was a fluctuation of soil meso-fauna population in fodder maize ecosystem and the gradual increase in the abundance of the soil meso-fauna prior to application of treatments. Highest population was noticed at 90 DAG (Fig. 1). The peak population occurred when there was sufficient food availability with optimum moisture in food, soil moisture, lower soil temperature, crop shade, less disturbance and settlement of soil particles due to rainfall after intercultivation. The abundance of soil meso-fauna was higher in cropping season and lower during non-cropping season. This may be due to low soil moisture content and increase in the soil temperature which might have reduced the abundance of fragile invertebrates. The present findings are in close agreement with the observations of Virupaksha (2011), Narasa Reddy (2012), GolivePrashanthi (2014) and Mahesh and Kumar (2016) who reported two peaks of the soil fauna during the post monsoon period (September-October) and lower population in pre-monsoon period (May-June) in soybean ecosystem.

\section{Relationship between abiotic factors and abundance of soil meso-fauna}

A significant positive relationship existed between the abundance of soil meso-fauna and abiotic factors Viz., maximum and minimum relative humidity, total rainfall, and soil moisture Insitu. However, sunshine hours and minimum soil temperature showed negative significant correlation with soil meso-fauna. Similar negative correlation with soil temperature was recorded for Acari in deciduous forest (Sinha et al., 1991) and soil insects in Dalbergia sissoo (Shukla et al., 1996). Abiotic edaphic factors like moisture and temperature are known to have a marked influence on soil organisms. Soil temperature and moisture have been shown to be of great importance in determining the abundance and diversity of soil fauna (Narula et al., 1996). Data revealed that irrespective of treatments the abundance of soil arthropods had a positive relationship with the soil moisture and a negative relationship to soil temperature (Table 1). It was observed that under specific conditions of the field experiment conducted, the community of soil arthropods in general was affected negatively rather than positively by high soil temperature, which is connected with the effect of evaporation and decrease in the soil moisture. It is well known fact that low moisture results in migration, lower reproduction and higher mortality of soil arthropods. Therefore, drought stress might have reduced the abundance and diversity of soil arthropods. Similar results were reported by Hazra (1981). Vats and Narula (1990) reported that population density of soil fauna was negatively correlated with temperature in both habitats (forest and field), but soil moisture was positively correlated in cereal fields and negative in forest.

The present results are in line with the observations on meso-faunal activity in relation to abiotic factors by Abhilasha (2013) and Golive Prashanthi (2014). Maximum and minimum temperature of the atmosphere, maximum soil temperature and Insitu soil temperature showed negative non-significant relationship with soil meso-fauna abundance. 
Table.1 Correlation between soil meso-fauna and abiotic factors in fodder maize ecosystem

\begin{tabular}{|c|c|c|c|c|c|c|c|c|c|c|}
\hline Particulars & $\begin{array}{l}\text { Max. } \\
\text { temperature }\end{array}$ & $\begin{array}{l}\text { Min. } \\
\text { temperature }\end{array}$ & $\begin{array}{c}\text { Max. } \\
\text { RH }\end{array}$ & $\begin{array}{c}\text { Min. } \\
\text { RH }\end{array}$ & $\begin{array}{l}\text { Sunshine } \\
\text { hours }\end{array}$ & $\begin{array}{c}\text { Total } \\
\text { rainfall }\end{array}$ & $\begin{array}{c}\text { InsituSoil } \\
\text { moisture }\end{array}$ & $\begin{array}{c}\text { Max. Soil } \\
\text { temperature }\end{array}$ & $\begin{array}{c}\text { Min. Soil } \\
\text { temperature }\end{array}$ & $\begin{array}{c}\text { Insitu }^{1} \\
\text { Soil } \\
\text { Temp }\end{array}$ \\
\hline $\begin{array}{l}\text { Soil meso- } \\
\text { fauna }\end{array}$ & -0.398 & -0.035 & $0.496 *$ & $0.565 * *$ & $-0.465^{*}$ & $0.516 *$ & $0.558 * *$ & -0.265 & $-0.533^{*}$ & -0.002 \\
\hline
\end{tabular}

** Significant at $0.01 \%$ level.

* Significant at $0.05 \%$ level.

RH: Atmospheric relative humidity

1: Insitu Soil temperature in experimental plot at the time of sampling

Table.2 Regression equation between soil meso-fauna and abiotic factors in fodder maize ecosystem

\begin{tabular}{|l|l|l|}
\hline Particulars & \multicolumn{1}{|c|}{$\begin{array}{c}\text { Regression equation } \\
\text { Value }\end{array}$} \\
\hline $\begin{array}{l}\text { Meso- } \\
\text { fauna }\end{array}$ & $\begin{array}{l}\mathrm{Y}^{2}=-29.450+0.321 \mathrm{X}_{1}+0.080 \mathrm{X}_{2}+0.001 \mathrm{X}_{3}-0.035 \mathrm{X}_{4}+0.927 \mathrm{X}_{5}-0.017 \mathrm{X}_{6}+0.386 \mathrm{X}_{7}+0.454 \mathrm{X}_{8}- \\
0.276 \mathrm{X}_{9}+0.107 \mathrm{X}_{10}\end{array}$ \\
\hline
\end{tabular}

$\mathrm{a}=$ Constant

$\mathrm{X} 1=$ Total rainfall

$\mathrm{X} 2=$ Maximum temperature

X3 = Minimum temperature X4= Maximum relative humidity X5= Minimum relative humidity

$\mathrm{X} 6=$ Sunshine hours X7= Insitusoil moisture X8= Maximum Soil temperature

$\mathrm{X} 9=$ Minimum Soil temperature $\mathrm{X}_{10=}$ Insitu soil temperature

Table.3 Stepwise regression analysis showing the significant abiotic variables against soil meso-fauna

\begin{tabular}{|c|c|c|c|c|c|}
\hline Variables & Regression co-efficient & Standard error & 't' value & 'F' value & $\mathbf{R}^{2}$ value \\
\hline Minimum RH & 0.565 & 0.311 & $2.981 * *$ & 8.887 & 0.283 \\
\hline
\end{tabular}


Fig.1 Impact of abiotic factors on soil meso-fauna

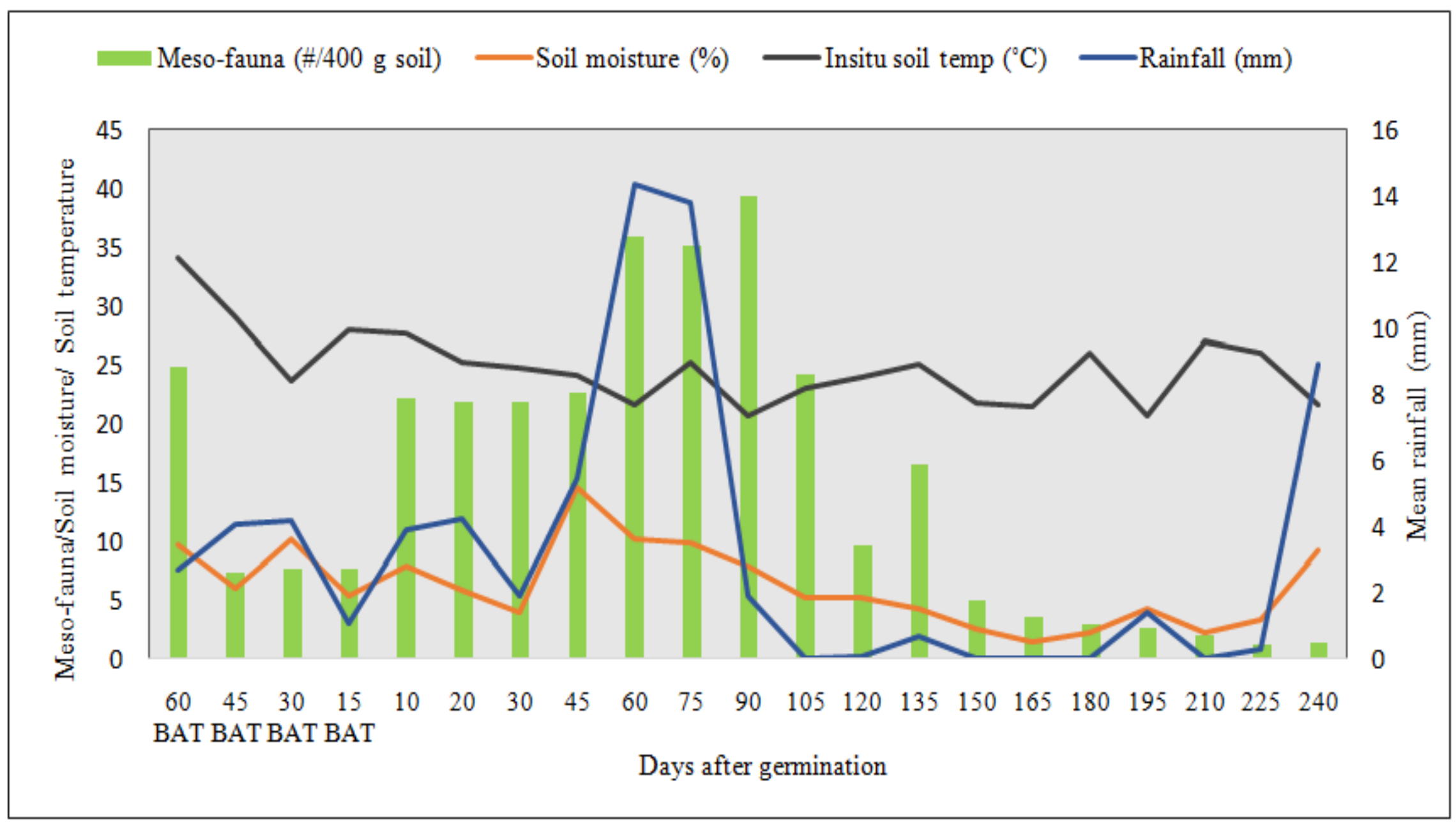


The contribution of abiotic factors on the abundance of soil meso-fauna was 31.9 per cent (Table 2). When the data was subjected to multiple linear regression analysis, the results showed that the influence of minimum relative humidity on the abundance of soil meso-fauna was up to 28.3 per cent. Further, the results indicated that with an unit change of minimum relative humidity would lead to increase of 0.565 units in soil meso-faunal abundance (Table 3).

It is concluded in the present study that maximum and minimum relative humidity, total rainfall and Insitu soil moisture had positive significant relationship with soil meso-fauna. It clearly says that, thediversity and abundance of the soil fragile invertebrates depends on the moisture content in the soil. The variation in impact of abiotic factors on soil meso-fauna may be due to prevailing cropping system, soil type, rainy days, sunshine hours and wind velocity etc. Present investigation also revealed that the soil fauna was predominant during rainy season (JulyDecember) with peak population in the month of October in the fodder maize ecosystem.

\section{References}

Abhilasha, C. R. 2013. Influence of abiotic factors on soil macro and meso faunal population in organic farming ecosystem. M.Sc. (Agri) Thesis, Uni. Agric. Sci., Bangalore, p. 158.

Banerjee, S. 1976. Micro arthropods and nitrate content of soil. Acta Arachnol, 26(1):47-50.

Bhattacharya, J. and Bhattacharya, T., 1987. Changes in the abundance of soil microarthropods in two contrasting sites in the Durgapur Industrial Area. J. Soil Biol. Ecol., 7(2): 110-121.

Golive Prashanthi. 2014. Impact of crop rotation on soil fauna in organic farming ecosystem. M.Sc. (Agri) Thesis, Uni.
Agric. Sci., Bangalore, p. 154.

Hazra, A. K. and Choudhuri, D. K., 1981. Studies on the distribution of Collembola population in two different soil conditions (Gangetic alluvium and Laterite soil) in relation to some major edaphic factors. In: Progress in Soil Biology and Ecology in India. UAS Tech. Series No. 37: 131 - 142.

Klironomos, J.N. and Kendrick, W.B., 1995. Stimulative effects of arthropods on endomycorrhizas of sugar maple in the presence of decaying litter. Funct. Ecol., 9:528-530.

Mahesh, H. M. and Kumar, N. G., 2016.Influence of FYM and NPK on soil meso-faunal abundance in fodder maize ecosystem. The Ecoscan, 10(3\&4): 481-484.

Narasa Reddy, G. 2012. Studies on the interrelationship between soil mesofauna and nematodes in organic farming system. M.Sc. (Agri) Thesis, Uni. Agric. Sci., Bangalore, p. 158.

Narula, A., Vatsa, L. K. and Handa, S., 1996. Soil arthropods of a deciduous forest stand. Ind. J. Forestry., 19(3): 285-288.

Shukla, R. N., Sharma, P. S. and Masih, R., 1996. Soil insect population from three sites in Rewa (M.P.) In: Soil Organisms and Sustainability. (Eds. D.Rajagopal, Radha D Kale and Kubra Bano), Indian Society of Soil Biology and Ecology, University of Agricultural Sciences, Bangalore, pp. 242-250.

Sinha, P. B.,Sen, S. S., Zahidi, A. P. and Naqvi, A. H., 1991. Comparative study on the ecology of soil mesofauna in a vegetable garden and a deciduous forest at Ranchi, India. In: Advances in management and conservation of soil fauna (Eds. Veeresh, G. K., Rajagopal, D. and Viraktamath, C. A.). Oxford and IBH publishing Co. Pvt. Ltd., New Delhi, pp. 419-427.

Vats, L. K. and Narula, A., 1990. Soil 
arthropods of cropland and forest land. Ann. Ent., 8(2): 39-42.

Virupaksha. 2011. Development of conservation practices for below ground biodiversity in soybean ecosystem. M.Sc. (Agri) Thesis, Uni. Agric. Sci., Bangalore, p. 191.

Wookey, P. A., Aerts, R., Bardgett, R. D., Baptist, F., Brathen, K. A., Cornelissen,
J. H. C., Gough, L., Hartley, I. P., Hopkins, D. W., Lavorel, S. and Shaver, G. R., 2009. Ecosystem feedbacks and cascade processes: understanding their role in the responses of Arctic and alpine ecosystems to environmental change. Global Change Biology, 15(5), 1153-1172.

\section{How to cite this article:}

Mahesh, H. M. and Kumar, N. G. 2020. Influence of Abiotic Factors on Soil Meso-fauna in Organically Cultivated Fodder Maize Eco System. Int.J.Curr.Microbiol.App.Sci. 9(02): 25962602. doi: https://doi.org/10.20546/ijcmas.2020.902.296 